\title{
Possible Competitive Displacement of Planorbids by Melanoides tuberculata in Minas Gerais, Brazil
}

\section{Carlos Tito Guimarães ${ }^{+}$, Cecília Pereira de Souza, Delza de Moura Soares}

\author{
Laboratório de Malacologia, Centro de Pesquisas René Rachou-Fiocruz, Av. Augusto de Lima 1715, 30190-002 \\ Belo Horizonte, MG, Brazil
}

Several species of snails, including Pomacea haustrum, Marisa cornuarietis and Helisoma duryi, have been identified as probable competitors and/or predators of planorbid intermediate hosts of Schistosoma. During the last few years, studies carried out in the Caribbean region have shown reductions and even disappearances of populations of Biomphalaria glabrata and $\mathrm{B}$. straminea in breeding places where the snail Melanoides tuberculata was introduced. Observations made over a period of 10 years in two lakes close to Belo Horizonte, MG, showed that there were marked reductions in autochthonous populations of $\mathrm{B}$. glabrata and B. straminea after the arrival of $\mathrm{M}$. tuberculata, both Biomphalaria species disappearing completely after eight years.

Key words: interspecific competition - Melanoides tuberculata - Biomphalaria glabrata -

Biomphalaria straminea - Brazil

A wide variety of different species, from bacteria to mammals, have been cited as probable competitors and/or predators of medically important molluscs (Michelson 1957, Ferguson 1972, Paraense 1987). The first studies on this type of control were published by Japanese researchers (Myioshima \& Igakkai 1917, Yuki \& Igakkai 1919) who suggested the use of lampyrid (Coleoptera) larvae and carp in the biological control of the intermediate hosts of Schistosoma japonicum (Katsurada, 1904). The use of molluscs in the biological control of the intermediate hosts of Schistosoma was stimulated in 1956 with the publication of the first studies involving the ampullarid Marisa cornuarietis (L.) in Puerto Rico (Chernin et al. 1956). Since then, various other molluscs including Helisoma duryi (Wetherby, 1879); Bulinus tropicus (Krauss, 1848) and Physa acuta (Draparnaud, 1805), have been indicated as probable predators and/or competitors of the snails that act as intermediate hosts of Schistosoma (Michelson 1957). More recently, reductions and even disappearances of Biomphalaria glabrata (Say, 1818) and $B$. straminea (Dunker, 1848) populations have been reported in the Caribbean region following the introduction of Melanoides tuberculata Müller, 1774

${ }^{+}$Corresponding author: Fax: +55-31-3295.3115. E-mail: tito@cpqrr.fiocruz.br

Received 14 May 2001

Accepted 25 July 2001
(Prosobranchia: Mesogastropoda) to their breeding places (Pointier \& McCullough 1989, Pointier et al. 1991, Pointier \& Guyard 1992, Pointier 1993, Pointier \& Giboda 1999). However, the impact of $M$. tuberculata is varies according to the type of habitat. Thus M. tuberculata and B. glabrata may coexist in heterogeneous and unstable habitats such as marshy areas adjacent to mangroves in Guadeloupe (Pointier et al. 1993). The medical importance of $M$. tuberculata (= Thiara tuberculata) lies in its role as an intermediate host of trematode parasites. In the Far East in the transmission cycles of both Paragonimus westermani (Kerbert, 1878), (Trematoda: Troglotrematidae) and Clomorchis sinensis (Cobdold, 1875), (Trematoda: Opistorchiidae) parasites of the respiratory system and bile ducts of man, respectively (Souza \& Lima 1990).

The influence of $M$. tuberculata on the population densities of B. glabrata, B. tenagophila and $B$. straminea in the laboratory was evaluated in the present study. Autochthonous populations of $B$. glabrata and $B$. straminea were also evaluated concurrently in two lakes near Belo Horizonte, MG, following the arrival of the thiarid.

\section{MATERIALS AND METHODS}

Field studies - The studies were carried out in two lakes, one near Vianópolis in the municipality of Betim (19 $58^{\prime}$ 'S, $\left.44^{\circ} 11^{\prime} \mathrm{W}\right)$ and the other near the municipality of Prudente de Morais $\left(19^{\circ} 28^{\prime}\right.$, $44^{\circ} 09^{\prime} \mathrm{W}$ ) in the Belo Horizonte Mesoregion of Minas Gerais, situated 50 and $70 \mathrm{~km}$ respectively from the city of Belo Horizonte. The lake at Vianópolis, the result of the damming of a spring, had a perimeter of almost $350 \mathrm{~m}$ and a mean depth 
of $2 \mathrm{~m}$. Snail collections were made twice per year, once in each semester, from April 1991 until December of 1999 at ten collecting stations, each of which occupied $10 \mathrm{~m}$ of the lake margin. The autochthonous species in this lake was B. glabrata and the thiarids appeared in May 1994. The lake at Prudente de Morais had a perimeter of almost 880 $\mathrm{m}$ and mean depth of $2.5 \mathrm{~m}$, and was formed by the damming of a stream. Two collections per year were also made in this lake from May 1990 to November 1999 in stations laid out as detailed above. The autochthonous species in this lake was $B$. straminea and the thiarids appeared for the first time in May 1993. Collections involved the same person dipping at one-metre intervals at each station. Perforated metal dippers with wooden handles were used (Souza \& Lima 1990). The thiarids captured were counted, measured and returned to the same breeding place. The planorbids were taken back to the laboratory, counted, measured and examined under the stereomicroscope to verify the presence or absence of Schistosoma cercariae. They were returned to the same breeding places on the following day.

\section{RESULTS}

The results shows a reduction in the number of B. straminea captured in Lake 1 from the third year of observations onwards, this trend increasing markedly after the fifth year, while B. glabrata numbers dropped after the fourth year in Lake 2 (Table). The final captures of B. straminea (one specimen) in Lake 1 and of B. glabrata (one specimen) in Lake 2 occurred in May 1996. On the other hand, the numbers of $M$. tuberculata increased gradually in the two lakes throughout the observation period (Table). None of the planorbids captured was infected by Schistosoma mansoni Sambon, 1907 (Trematodea: Schistosomatidae). However, 128 specimens of Physa sp. were captured during the study. Members of the families Graminaceae and Ciperaceae constituted the predominant vegetation in both lakes.

\section{DISCUSSION}

Biological control studies of medically important molluscs have been the targets of criticism and scepticism over the years, especially with respect to results obtained in the laboratory. Since the conditions under which the experiments are run do not reflect the natural situation, the results are not generally considered to have great practical value. However, Odum (1972) drew attention to the importance of these experiments by affirming that the study of laboratory populations contributed to the understanding of natural ones, although field observations and experiments should always be con-

\section{TABLE}

Specimens of Biomphalaria straminea (Bs), B. glabrata $(\mathrm{Bg})$ and Melanoides tuberculata $(\mathrm{Mt})$ captured in two lakes, one in Prudente de Morais (PM) and the other in Vianópolis (V), Minas Gerais, Brazil from May 1990 to December 1999

\begin{tabular}{lrrrrr}
\hline & \multicolumn{4}{c}{ Snails captured } \\
\cline { 2 - 3 } & \multicolumn{2}{c}{ Lake 1 $(\mathrm{PM})$} & & \multicolumn{2}{c}{ Lake $2(\mathrm{~V})$} \\
\cline { 2 - 3 } \cline { 5 - 6 } Month & Bs & M t & & Bg & M t \\
May/90 & 985 & 0 & & - & - \\
Dec/90 & 1,319 & 0 & & - & - \\
Apr/91 & 624 & 0 & & 221 & 0 \\
Nov/91 & 694 & 0 & & 301 & 0 \\
May/92 & 812 & 0 & & 969 & 0 \\
Dec/92 & 1,002 & 0 & & 1,374 & 0 \\
May/93 & 503 & 52 & & 137 & 0 \\
Nov/93 & 309 & 96 & & 191 & 0 \\
May/94 & 4 & 94 & & 8 & 26 \\
Nov/94 & 0 & 118 & & 4 & 108 \\
May/95 & 0 & 528 & & 0 & 382 \\
Nov/95 & 0 & 812 & & 0 & 443 \\
May/96 & 1 & 284 & & 1 & 831 \\
Dec/96 & 0 & 432 & & 0 & 1,322 \\
Jun/97 & 0 & 484 & & 0 & 749 \\
Dec/97 & 0 & 840 & & 0 & 1,007 \\
May/98 & 0 & 984 & & 0 & 801 \\
Nov/98 & 0 & 1,403 & & 0 & 1,313 \\
May/99 & 0 & 745 & & 0 & 886 \\
Dec/99 & 0 & 1,003 & & 0 & 1,214 \\
\hline & & 0 & & &
\end{tabular}

sidered preferable. In the present study both laboratory and field observations were made with a view to evaluating the interactions between introduced populations of thiarids and autochthonous ones of planorbids. Experiments performed by Guimarães (1983) with $P$. haustrum and $P$. marmorata (Guimarães et al. 1987) provided similar results to those of the present study. In the field a reduction was followed by the disappearance of the planorbid populations (Table). Another unidentified factor may have contributed to the decline of the $B$. glabrata population after May 1993, a year before the appearance of $M$. tuberculata.

Part of this reduction could be attributed to the phenomenon of "one way competition" (Odum 1972) in which one species releases substances harmful to another into the water, as pointed out by Gomez et al. (1989) who reported that Thiara granifera probably produces one or more chemical factors that reduce the fecundity of $B$. glabrata. Another important factor is habitat type, which affects whether or not thiarids and planorbids are able to co-exist.

Several other interactions, in addition to those previously cited, are probably important in caus- 
ing population reductions, including the occupation by introduced species of new areas (Dajoz 1973). According to this author, the absence of similar species in the area would facilitate the development and the colonization of the species introduced. As the process advances competitive exclusion or Gause's Principle may result, by which two species with the same requirements are unable to coexist, resulting in the elimination of one of them after a certain period. Farias (1999) collected 2,400 specimens of thiarids in the municipality of Sumidouro, a focus of Schistosoma transmission in the Brazilian State of Rio de Janeiro. He suggested that thiarid numbers apparently were increasing through competitive exclusion of $B$. glabrata. Recently, Guimarães (unpublished data) observed a reduction and later disappearance of the $B$. straminea population in a small lake in the municipality of Esmeraldas, MG, after the appearance of $M$. tuberculata. Several authors have reported the reduction and subsequent disappearance of populations of $B$. glabrata and $B$. straminea on various Caribbean islands after the introduction of $T$. granifera and M. tuberculata (Prentice 1983, Pointier \& McCullough 1989, Pointier et al. 1989, 1991, Pointier \& Guyard 1992, Pointier 1993, Pointier \& Giboda 1999). However, Freitas and Santos (1995) drew attention to the fact that high densities of $M$. tuberculata $\left(16,000\right.$ individuals $\left./ \mathrm{m}^{2}\right)$ in the reservoir of Olhos D'Água in Belo Horizonte, MG, had not altered the population density of B. tenagophila in that locality. Mkoji et al. (1992) also questioned the role of $M$. tuberculata as a biological control agent of molluscs, concluding that it was able to co-exist with B. pfeiffer and other pulmonate snails in Kenya without displacing them completely.

In the present study, carried out in two Schistosoma-endemic municipalities in the Mesoregion of Belo Horizonte, observations made over ten years showed marked reductions in planorbid populations following the appearance of $M$. tuberculata in two lakes. Both B. glabrata and of B. straminea completely disappeared from the capture stations after eight years, suggesting that competitive exclusion by $M$. tuberculata had occurred. Further observations and captures will be made in these lakes to determine whether or not the planorbids will reappear in the future.

\section{REFERENCES}

Chernin E, Michelson EH, Augustine DL 1956. Studies on the biological control of schistosome-bearing snails. I. The control of Australorbis glabratus populations by the snail, Marisa cornuarietis, under laboratory conditions. Am J Trop Med Hyg 5: 297-307.

Dajoz R 1973. Ecologia Geral, 2 nd ed., Vozes Petrópolis, and Universidade de São Paulo, São Paulo, 472 pp.
Farias CAM 1999. Controle da esquistossomíase e outras parasitoses intestinais em localidades de Sumidouro (RJ), por medidas integradas. VII Reunião Anual de Iniciação Científica, Fundação Oswaldo Cruz, p. 123.

Ferguson FF 1972. Biological control of schistosomiasis snails. Proceedings of a Symposium on the Future of Schistosomiasis Control, Tulane University, New Orleans, p. 85-91.

Freitas JR, Santos MBL 1995. Current advances on the study of snail-snail interactions, with special emphasis on competition process. Mem Inst Oswaldo Cruz, 90: 261-269.

Gomez JD, Vargas M, Malek EA 1989. Biological control of Biomphalaria glabrata by Thiara granifera under laboratory conditions. Trop Med Parasitol 41: 43-45.

Guimarães CT 1983. Controle biológico: Pomacea haustrum Reeve, 1856 (Mollusca, Pilidae) sobre planorbídeos, em laboratório. Rev Saúde Pública 17: 138-147.

Guimarães CT, Soares DM, Schuster LMR 1987. The influence of Physa marmorata (Mollusca; Physidae) on the oviposition of several planorbid hosts of Schistosoma mansoni. Mem Inst Oswaldo Cruz 82: 439440.

Michelson EH 1957. Studies on the biological control of schistosome-bearing snails. Predators and parasites of fresh-water mollusca: A review of the literature. Parasitology 47: 413-426.

Miyoshima K, Igakkai JZ 1917. Lampyrid larva, an enemy of the intermediate host of Schistosoma japonicum. In: KS Warren \& VA Newill 1967. Schistosomiasis: A Bibliography of the World's Literature from 1852 to 1962, The Press of Western Reserve University Ohio, USA, Vol I: 395 pp., Vol II: 598 pp.

Mkoji GM, Mungai BN, Koech DK, Hofkin BV, Loker ES, Kihara JH, Kageni FM 1992. Does the snail Melanoides tuberculata have a role in biological control of Biomphalaria pfeifferi and other medically important African pulmonates? Ann Trop Med Parasitol 86: 201-204 .

Odum EP 1972. Ecologia Pioneira, 3rd ed., São Paulo, $201 \mathrm{pp}$.

Paraense WL 1987. Control of schistosomiasis mansoni: an outlook from current expectation. Mem Inst Oswaldo Cruz 82 (Suppl. IV): 1-12.

Pointier JP 1993. The introduction of Melanoides tuberculata (Mollusca: Thiaridae) to the island of Saint Lucia (West Indies) and its role in the decline of Biomphalaria glabrata, the snail intermediate host of Schistosoma mansoni. Acta Trop 54: 13-18.

Pointier JP, Giboda M 1999. The case for biological control of snail intermediate hosts of Schistosoma mansoni. Parasitol Today 15: 395-397.

Pointier JP, Guyard A 1992. Biological control of the snail intermediate hosts of Schistosoma mansoni in Martinique, French West Indies. Trop Med Parasitol 43: 98-101.

Pointier JP, McCullough F 1989. Biological control of the snail hosts of Schistosoma mansoni in the Carib- 
176 Control of Planorbids by M. tuberculata in MG • Carlos Tito Guimarães et al.

bean area using Thiara spp. Acta Trop 46: 147-155.

Pointier JP, Frederic M, Mazille V 1991. Biological control of Biomphalaria glabrata by Melanoides tuberculata on Désirade Island, French West Indies. J Med Appl Malacol 3: 49-52.

Pointier JP, Guyard A, Mosser A 1989. Biological control of Biomphalaria glabrata and B. straminea by the competitor snail Thiara tuberculata in a transmission site of schistosomiais in Martinique, French West Indies. Ann Trop Med Parasitol 83: 263-269.

Prentice MA 1983. Displacement of Biomphalaria glabrata by the snail Thiara granifera in field habi- tats in St Lucia, West Indies. Ann Trop Med Parasitol 77: $51-59$

Souza CP, Lima LC 1990. Moluscos de Interesse Parasitológico do Brazil, Série Esquistossomose 1, Centro de Pesquisas René Rachou, Fundação Oswaldo Cruz, Belo Horizonte, 76 pp.

Yuki G, Igakkai JZ 1919. The intermediate host of Schistosoma japonicum and the carp. J Kyoto Med Ass 16: 12. In KS Warren \& VA Newill 1967. Schistosomiasis. A Bibliography of the Word's Literature from 1852 to 1962, The Press of Western Reserve University Ohio, Vol I: 395 pp., Vol I: 598 pp. 